Agro-Science Journal of Tropical Agriculture, Food, Environment and Extension Volume 18 Number 1 (January 2019) pp. 1-6

ISSN 1119-7455

\title{
EFFECT OF AGROCHEMICAL RELATED ILLNESS ON TECHNICAL EFFICIENCY OF LOWLAND RICE FARMERS IN NIGER AND OGUN STATES NIGERIA
}

\author{
${ }^{* 1}$ Oseghale A.I., ${ }^{2}$ Ayinde I.A., ${ }^{2}$ Shittu A.M. and ${ }^{3}$ Adeofun C.O. \\ ${ }^{1}$ Department of Agricultural Economics and Farm Management, \\ Federal University of Technology, P.M.B. 65, Minna, Niger State, Nigeria \\ ${ }^{2}$ Department of Agricultural Economics and Farm Management, \\ Federal University of Agriculture Abeokuta, Ogun State \\ ${ }^{3}$ Department of Environmental Management and Toxicology, \\ Federal University of Agriculture Abeokuta, Ogun State \\ Corresponding author's email: itodine.agatha@ futminna.edu.ng
}

\begin{abstract}
This study assessed the effect of agrochemical related illness on technical efficiency of lowland rice farmers in Niger and Ogun States of Nigeria. Multi-stage sampling technique was used to obtain primary data from a cross section of 304 rice farmers in both states through the use of questionnaire/interview guide. Data were analyzed through the use of descriptive statistics, cost of illness (COI) estimation, data envelopment analysis (DEA) and Tobit regression. The study revealed that cough was the most (58.10\%) prevalent health symptom associated with the use of agrochemicals in the study area and that $46.70 \%$ of the rice farmers relied on self-medication. Also, the COI estimation revealed that a total of $\$ 4,273$ was expended per treatment. The results of the DEA showed that rice farmers in the study area were technically inefficient with a mean score of 0.54, and this was influenced by age $(\alpha-0.002, p<0.05)$, sex $(\alpha-0.243, p<0.01)$, distance from home to farm $(\alpha-0.007, p<0.10)$, number of farm plots $(\alpha-0.007, p<0.10)$, cost of illness due to agrochemicals use $(\alpha-5.510 p<0.10)$, location $(\alpha-0.298, p<0.01)$, farm size $(\alpha-0.112, p<0.01)$, and use of fertilizer $(\alpha-0.308, p<0.01)$. The study concluded that farmers in the study area were exposed to agrochemical related illnesses and that the exposure influenced their technical efficiency negatively. The study, therefore, recommends the inclusion/enforcement of safety and health information pertaining to agrochemical use on extension packages. Also, policies on land reforms should be tailored towards reducing land fragmentation.
\end{abstract}

Key words: treatment, cost, tobit, economic, application

\section{INTRODUCTION}

Agrochemical can be defined as any chemical substance or mixture of substances intended for preventing, destroying, repelling, or mitigating the effect of any pest of plants and animals (Asogwa and Dongo, 2009). They include pesticides such as herbicides, insecticides, rodenticides, fungicides, molluscides, nematicides, avicides, repellents and attractants as well as fertilisers used in agriculture, public health, horticulture, food storage. Agrochemical is considered a vital component of modern farming, playing a major role in maintaining high agricultural productivity (Popp et al., 2013). Despite their popularity and extensive use, serious concerns about health risks arising from the exposure of farmers when mixing and applying pesticides or working in treated fields and from residues on food and in drinking water for the general population have been raised (Dabady and Tulk, 2015). These health risks can influence farmer's ability to fully utilize farm inputs at their disposal and this can translate into lower level of technical efficiency. Farmers' health influences the agricultural system since poor health leads to decrease in farm workers' capability and reduces their ability to explore and adopt innovation and this in turn reduces their level of efficiency (Munongo and Chitungo, 2013). In addition, family time is diverted to caring for the sick and it could also lead to loss of savings and assets in the course of dealing with diseases and its consequences. 
Household spending on illness can be classified into two; direct and indirect. Direct spending include payment for drugs, consultation, laboratory test and transportation costs to and from the health facility while the indirect spending includes productive time lost due to illness and reduction in saving and investment (Abeynayake et al., 2015). The main consequence of illness is a reduction in the labour workforce which in turn translates into a decrease in household production and income. Due to illness and other factors such as underutilization of farm resources, farmers are unable to produce quantities that can meet the rice consumption demand of Nigeria which increased from 1.5 million tonnes in $2014 / 2015$ to 1.7 million tonnes in 2015/2017 as reported by Nzeka et al. (2016). Agrochemicals are one of the vital farm inputs used in especially lowland rice production hence there is a need to address the health problems associated with their application so as to prevent output losses due to such illness. Lowland rice farming is popular in Niger State as well as in southern Nigeria (Obalum et al., 2012, 2014), which includes Ogun State. Therefore, this study assessed the effect of agrochemical related illnesses on technical efficiency of lowland rice farming in these states.

\section{MATERIAL AND METHODS}

\section{Area of Study}

The study was carried out in Niger and Ogun states in the North Central and South West zones of Nigeria respectively. Niger State is located between Latitude $8^{\circ} 22^{\prime} \mathrm{N}$ and $11^{\circ} 30^{\prime} \mathrm{N}$ and Longitude $3^{\circ} 30^{\prime} \mathrm{N}$ and $7^{\circ} 20^{\prime} \mathrm{E}$ and it covers about $86,000 \mathrm{sq} . \mathrm{km}^{2}$ (about 8.6 million hectares), (Niger State GIS, 2007) The State experiences distinct dry and wet seasons. The mean annual rainfall varies $1100 \mathrm{~mm}$ in the north to $1600 \mathrm{~mm}$ in the south while the mean minimum and maximum temperature is $26^{\circ} \mathrm{C}$ and $36^{\circ} \mathrm{C}$ respectively. The 2006 census, puts the population at 3.95 million people with a projection of about 5.21 million people in year 2016 based on the $3.2 \%$ growth rate (NPC, 2014) and a population density of 284 persons per square km (Niger State GIS, 2007).

Ogun State is located in the south western part of Nigeria. It lies between Latitude $6.9098^{\circ} \mathrm{N}$ and Longitude $3.2584^{\circ} \mathrm{E}$ and it covers about 16,980 sq. $\mathrm{km}^{2}$ (National Bureau of Statistics (NBS, 2006). The State experiences distinct dry and wet seasons. The mean annual rainfall varies from $1050 \mathrm{~mm}$ in the north to $1280 \mathrm{~mm}$ in the south while the mean minimum and maximum temperature is $23^{\circ} \mathrm{C}$ and $32^{\circ} \mathrm{C}$ respectively. The rainy season starts in March and ends in November and it is followed by the dry season which starts in November/December and extends to March/April of the succeeding year. The state characterised by its rain forest, swampy forest and derived savannah vegetation. The 2006 census, puts the population of Ogun State at 3.75 million people with a projection of about 5.22 people in year 2016 based on the growth rate of $3.2 \%$ (NPC, 2014) and a population density of 222 persons per square km (NBS, 2016).

\section{Sources and Method of Data Collection}

This study was based on primary data collected by the administration of questionnaire on rice farmers (who constituted the study population) located in Niger and Ogun States, respectively.

\section{Sampling Technique}

Multistage sampling technique was used to select 300 rice farmers from Niger and Ogun States of Nigeria. In the first stage, proportionate sampling technique (on a ratio 1:1.5) was used to select two zones (Zones 1 and 3) out of the three agricultural zones selected in Niger state while three zones out of the four agricultural zones were selected from Ogun State. In the second stage, five local government areas were selected from Zone 1 (given that it is the major rice producing zone in the state), and one local government area from Zone 3 in Niger State. In Ogun State, one local government was selected from each of the zone using simple random sampling technique. This gives a total of nine (9) LGAs altogether.

In the third stage, systematic sampling technique was used to select 30 respondents from each of the LGAs in Niger State making a total of 180 respondents while40 respondents were selected from each of the LGAs in Ogun State making a total of 120 respondents. However only 266 respondents returned the questionnaire and were included in the analysis.

\section{Method of Data Analysis \\ Descriptive statistics}

Descriptive statistics such as mean, standard deviation, frequencies and percentages, was used to describe respondents by symptoms experienced and type of treatment sought during the course of illness. It was also used to describe the variables included in the DEA model.

\section{Economic cost of illness}

The economic cost of illness (COI) was calculated using the formula used by Abeynayake et al. (2015) and it is stated as:

$$
\mathrm{TCI}=\mathrm{TDC}+\mathrm{TIC}
$$

where TCI is total cost of illness (NGN); TDC is total direct cost, that is, cost incurred as a result of symptoms/impairment arising from the use of agrochemicals, including cost of drugs, herbs and doctor's consultations in addition to transportation to health facilities, hospital bills and laboratory tests; and TIC is ILP + ILO, where TIC is total indirect cost (NGN), ILP is income loss due to 
working hours loss (NGN), and ILO is income loss of caregiver (NGN). The health impairment and symptoms that fell into this analysis were cough, diarrhoea, cold and chest pain.

\section{Data Envelopment Analysis}

Estimate of technical efficiency was obtained by estimating an input oriented DEA model and it is specified as:

$$
T E_{n} \min _{\lambda_{i} \theta_{n}} \theta_{n}
$$

subject to;

$$
\begin{gathered}
\sum_{i=1}^{I} \lambda_{i} x_{i j}-\theta_{n} x_{n j} \leq 0 \\
\sum_{i=1}^{I} \lambda_{i} y_{i}-y_{n} \geq 0 \\
\sum_{i=1}^{I} \lambda_{i}=1 \\
\lambda_{i} \geq 0
\end{gathered}
$$

$\theta_{n}$ - a scalar less or equal to one and it defines the $\mathrm{TE}$ of field $\mathrm{n}$. Where; $\mathrm{Y}$ is rice output $(\mathrm{kg}) \mathrm{X}$ is a vector of inputs and it includes; $X_{i}$ - seed $(\mathrm{kg}) \mathrm{X}_{2}$ land (ha) $X_{3}$ - fertilizer (kg) $X_{4^{-}}$Land (ha) $X_{5}$ pesticide (g/a.i/ha) $X_{6}$ - Labour (mandays) When $\theta_{n}-1$, it indicates that field $n$ is technically efficient. However, a value less than 1 indicates that field $\mathrm{n}$ is technically inefficient. The inclusion of $\sum_{i=1}^{I} \lambda_{i}-1$ in equation 2 implies that TE for field $\mathrm{n}$ is calculated under variable returns to scale.

\section{Measurement of Variables}

Illness/impairment - the illness/impairment used in this study were based on farmers' observation as no medical test was carried out and agrochemical related illness reported in literature. Illness episode or treatment - implies from outset of illness till the rice farmer returns to his normal activities. Caregiver - the person who took care of the sick person during the occasion of illness. Mandays imply average male adult work of about $8 \mathrm{~h}$ a day.

\section{RESULTS AND DISCUSSIONS \\ Health Impairment Associated with Agrochemical Use in Rice Production}

Table 1 shows the health impairment associated with agrochemical use in the study area. Cough was the most prevalent as indicated by $55.9 \%$ and $61.5 \%$ of the rice farmers in Niger and Ogun States respectively. In addition, $26.3 \%$ and $9.0 \%$ of respondents in both locations indicated that they experienced cold and skin irritation, respectively. However, chest pain was not a common health impairment around the states since only $2 \%$ reported that they had experienced chest pain in Niger State while no respondents reported chest pain
Table 1: Health symptoms associated with agrochemical use in rice production

\begin{tabular}{llll}
\hline Symptoms & $\begin{array}{l}\text { Niger } \\
\text { State }\end{array}$ & $\begin{array}{l}\text { Ogun } \\
\text { State }\end{array}$ & Pooled \\
\hline Diarrhoea & $7(6.9 \%)$ & $2(3.1 \%)$ & $9(5.4 \%)$ \\
Cough & $57(55.9 \%)$ & $40(61.5 \%)$ & $97(58.1 \%)$ \\
Cold & $21(20.6 \%)$ & $23(35.4 \%)$ & $44(26.3 \%)$ \\
Chest pain & $2(2.0 \%)$ & $0(0.0 \%)$ & $2(1.2 \%)$ \\
Skin Disease & $15(14.7 \%)$ & $0(0 \%)$ & $15(9.0 \%)$ \\
\hline \multicolumn{4}{l}{ Source: Data from Field Survey 2015} \\
\multicolumn{2}{l}{}
\end{tabular}

in Ogun State. This is an indication that there are inherent issues associated with agrochemical application. More so, rice farmers who fall ill during the course of production have the tendency of underutilizing inputs at their disposal and this could translate into reduced output and farm profits. This study corroborates the findings of Truong et al. (1999), Damalas et al. (2011) and Ye et al. (2016) who reported cough, skin diseases and chest pain as some of the impairments associated with the use of agrochemical.

Type of Treatment Sought by Rice Farmers for Agrochemical-induced Health Impairments

Table 2 indicates the type of treatment sought by the rice farmers on the occasion of agrochemical induced health impairments. Most $(46.7 \%)$ of the respondents resorted to self-medication. This seems to be cheaper and available at local health facilities. However, self-medication was found to be dangerous because most drugs are designed to treat specific ailments and have high potency, dosage specific and they always have their side effects (West African Rescue Association (WARA, 2016). Also shown on the table is the fact that $31.1 \%$ employed the use of herbs while only about $5.4 \%$ and $0.6 \%$ of the rice farmers applied no treatment or took a rest respectively. The use of herbs as a means of treatment could be as a result of the ease of availability of herbs in the communities. The implication of this is that, farmers could be putting themselves at higher risks because they are unaware of their actual health status.

In addition, prolonged illness can lead to loss of rice farming knowledge, reduction of rice farmlands and invariably, a decline in household income. This finding is in line with Akinbode et al. (2011) who reported that local herbs and the use of self-medication were the first line of treatment in the occasion of illness even though the rice farmers in North central combined both orthodox and traditional treatment. Also, the study corroborated the findings of Alarima and Obikwelu (2018) who reported that Fulani agropastoralists settling in Ogun State of Nigeria relied on self-medication during the occasion of illness. 
Table 2: Type of treatments sought by respondents during illness

\begin{tabular}{llll}
\hline Type of Treatment & Niger State & Ogun State & Pooled \\
\hline No treatment & $6(5.9 \%)$ & $3(4.6 \%)$ & $9(5.4 \%)$ \\
Rest only & $1(1.0 \%)$ & $0(0.0 \%)$ & $1(0.6 \%)$ \\
Use of herbs & $25(24.5 \%)$ & $27(41.5 \%)$ & $52(31.1 \%)$ \\
Self-medication & $57(55.9 \%)$ & $21(32.3 \%)$ & $78(46.7 \%)$ \\
$\begin{array}{l}\text { Prescribed drugs } \\
\text { without test }\end{array}$ & $4(3.9 \%)$ & $9(13.8 \%)$ & $13(7.8 \%)$ \\
$\begin{array}{l}\text { Prescribed drug } \\
\text { after test }\end{array}$ & $5(4.9 \%)$ & \multicolumn{1}{c}{$3(4.6$} & $8(4.8 \%)$ \\
Admitted & $4(3.9 \%)$ & $2(3.1 \%)$ & $6(3.6 \%)$ \\
\hline
\end{tabular}

Source: Data from Field Survey 2015

Health Cost Associated with Agrochemicalinduced Health Impairments

The use of agrochemical comes with some health cost as shown on Table 3. The total direct cost was \#583 per illness episode while the time cost (opportunity cost of time loss as a result of care giving and absence from work) were $\$ 281$ and $\$ 3,407$ per treatment respectively. The total cost of illness in Niger and Ogun States were \$5,353 and N2, 877 respectively. The implication is that for an illness episode as a result of agrochemical use, farmer's lost almost 7 times the daily agricultural wage in the rice farming communities in Niger State and about 4 times in Ogun State. Also, absence from work as a result of illness could have a negative effect on their efficiency (Akinbode et al., 2011).

\section{Summary Statistics of Variables included in the DEA Model}

As shown in Table 4, the average output obtained by cultivating 1.7 ha of land was $4,937 \mathrm{~kg}$ (4.94 tonnes). This translates to 2.90tonnes per hectare, with an average of 45.6 man-days of labour used for the farming operations during the season. This is an indication that rice farmers around the states are small scale farmers because they cultivate less than 5 ha of land which is the benchmark according to Abubakar (2004) and Kakwagh et al. (2011).

\section{Technical Efficiency (TE) of Rice Farmers}

Table 5 shows the frequency distribution of the TE scores of the rice farmers in the study area. Majority $(61.9 \%)$ of the rice farmers were inefficient having technical efficiency score ranging from less than 0.31 to 0.50 with an average technical efficiency score of 0.54 . The TE is score is in close range with that obtained by Krishna $e t$ al., (2014) and Binuyo et al., (2016). This implies that rice farmers in the study areas did not utilize available resources adequately. Hence, technical efficiency in rice production can be increased by $46 \%$ through efficient use of available resources given the current state of technology. Further, $21.7 \%$ of rice farmers in Niger State had very high technical efficiency score ranging from 0.91 to 1.00. These farmers could be targeted as contact farmers to information facilitators and disseminators of recommended technologies amongst their peers. The presence of technical inefficiency is an indication that the rice farmers have the potentials for increasing output without increasing the use of inputs. And with the present competition for production resources, (Sustainable Development Solutions Network (SDSN, 2013), farmers have no option other than to improve on their technical efficiency in order to increase output for higher income. Age $(\alpha--0.002, \mathrm{p}<0.05)$, sex $(\alpha--0.243, \mathrm{p}<0.01)$, distance from home to farm $(\alpha-0.007, \mathrm{p}<0.10)$, number of farm plots $(\alpha-$ $0.007, \mathrm{p}<0.10)$, cost of illness due to agrochemical use $(\alpha--5.510 \mathrm{p}<0.10)$, location $(\alpha--0.298$, $\mathrm{p}<$ $0.01)$, farm size $(\alpha--0.112, \mathrm{p}<0.01)$ and use of fertilizer $(\alpha--0.308, \mathrm{p}<0.01)$ were the significant factors that influenced rice farmers level of technical efficiency (Table 6).

Table 3: Summary of health cost associated with illness

\begin{tabular}{llcl}
\hline $\begin{array}{l}\text { Cost of Treatment } \\
\text { (N/occurrence) }\end{array}$ & Niger State & Ogun State & Pooled \\
Total Direct Cost & 486.19 & 709.48 & 583.64 \\
Cost of Care giving & 138.00 & 466.65 & 281.45 \\
$\begin{array}{l}\text { Cost of Absence } \\
\text { from Work }\end{array}$ & 4729.77 & 1701.49 & 3407.98 \\
Total Indirect Cost & 4867.78 & 2168.14 & 3689.43 \\
\hline \multicolumn{4}{l}{ Source: Data from Field Survey 2015 }
\end{tabular}

Table 4: Summary of variables included in the DEA model

\begin{tabular}{ll}
\hline Variables & Quantity/Cost \\
\hline Output Quantity (kg) & 4937.46 \\
Quantity of Seed Planted (kg) & 79.06 \\
Land (ha) & 1.70 \\
Labour (man-days) & 45.6 \\
Agrochemical(gm/ a.i/ha) & 1583.63 \\
Fertilizer (kg) & 193
\end{tabular}

Source: Data from Field Survey 2015

Table 5: Distribution of rice farmers by technical efficiency scores

\begin{tabular}{llll}
\hline TE Scores & Niger State & Ogun State & Pooled \\
\hline Less than 0.31 & $29(17.5 \%)$ & $7(10 \%)$ & $36(15.3 \%)$ \\
$0.31-0.40$ & $26(15.7 \%)$ & $28(40.0 \%)$ & $54(22.9 \%)$ \\
$0.41-0.50$ & $42(25.3 \%)$ & $14(20.0 \%)$ & $56(23.7 \%)$ \\
$0.51-0.60$ & $18(10.8 \%)$ & $0(0.0 \%)$ & $18(7.6 \%)$ \\
$0.61-0.70$ & $8(4.8 \%)$ & $7(10.0 \%)$ & $15(6.4 \%)$ \\
$0.71-0.80$ & $0(0.0 \%)$ & $0(0.0 \%)$ & $0(0.0 \%)$ \\
$0.81-0.90$ & $7(4.2 \%)$ & $7(10.0 \%)$ & $14(5.9 \%)$ \\
$0.91-1.00$ & $36(21.7 \%)$ & $7(10.0 \%)$ & $43(18.2 \%)$ \\
Minimum & 0.12 & 0.30 & 0.12 \\
Maximum & 1.00 & 1.00 & 1.00 \\
Mean & 0.55 & 0.51 & 0.54 \\
\hline Source: Dat & & &
\end{tabular}

Source: Data from Field Survey 2015 
The result indicated that as rice farmers grow older they become less efficient in the use of production resources. This could possibly be ascribed to physical (dwindling strength), economic and psychological factors. Older farmers tend to have attachment to traditional ways of farming and they are generally risks averse (Polson and Spenser, 1991, Ajayi and Adeyemi 2016). The result contradicts the findings of Rahman et al. (2012) who found out that age had negative effect on technical inefficiency. It is however similar to Onyenekwe and Okorji (2015) who also found age to be significant in the same direction. Also, female rice farmers were more technically efficient than their male counterparts. In addition, farmers who have their farms located far away from home are more technically efficient. With respect to distance of farm to home, it was reported (Kassali et al., 2009) that the search for fertile lands could be the reason why farms are located far away from home. Also, farmers tend to minimize cost when their farms are located far from home. This is because many a times, farmers having their farms far away from home construct temporary sheds (to sleep on farm throughout the duration of major farming operations) located on their farms and this helps them save costs associated with transportation.

Also, farmers tend to pool their resources together to ease their movement from their place of residence to the farm. In addition, location of farms away from homes helps to reduce the effect of agrochemical on members of the households and community not involved in the farming activities thereby preventing health related cost. However, the coefficient for cost of illness was significant and negative implying that the higher the cost of illness the lower the level of technical efficiency. This could be explained based on the fact that farmers who took ill during the course of the farming season lost their time and resources while taking care of themselves. Similarly, the coefficient for location was negative implying that rice farmers located in Ogun state combine their resources better than their counterparts in Niger state. Results also revealed that farm size had an inverse relationship with technical efficiency, implying that as farmers increased the area of land cultivated, the level of technical efficiency reduced. This point to the fact that, relatively small farmers combine their resources better (Rosset, 1999). It could be also due to the scattered nature of their farms. These findings are corroborated by Binuyo et al. (2016), Onyenekwe and Okorji (2015), Bhatt and Bhat (2014) and Tchale (2009), who also reported that farm size had negative influence on technical efficiency. In addition, the number of farm plots influenced technical efficiency negatively. That is to say, the higher the number of plots the lower the level of technical efficiency. Higher number of farm
Table 6: Tobit regression results of the determinants of technical efficiency

\begin{tabular}{lll}
\hline Explanatory Variables & Coefficients & T-Ratio \\
\hline Age & $-0.002^{* * *}$ & -0.89 \\
Education & -0.020 & -0.62 \\
sex & $-0.243^{* * *}$ & -2.93 \\
Household size & -0.004 & -0.49 \\
Marital status & 0.067 & 1.05 \\
Distance to farm & $0.007 *$ & 1.85 \\
Extension contact & -0.001 & -0.10 \\
Credit used & 3.740 & 1.28 \\
No of farm plots & $-0.0065^{* * *}$ & -1.76 \\
Cost of illness & $-5.510^{*}$ & -1.87 \\
Location & $-0.298^{* * *}$ & -3.56 \\
Farm Size & $-0.112^{* * *}$ & -4.81 \\
Use fertilizer & $-0.308^{* * *}$ & -3.22 \\
Use herbicide & -0.109 & -0.98 \\
Use insecticide & -0.080 & -0.54 \\
Constant & 1.593 & 9.38 \\
Sigma & 0.216 & \\
LR Chi ${ }^{2}(13)$ & 86.010 & \\
Log-likelihood & 18.280 & \\
\hline$* * *, * *, *$ implies & significance at $1 \%, 5 \%$ & and $10 \%$ \\
respectively Source: Data from Field Survey 2015 & \\
\hline
\end{tabular}

plots signifies a high degree of land fragmentation. Land fragmentation is a common feature of rural farming as most of the rural farmers acquire their lands through inheritance and this stands as an obstacle to farm expansion and agricultural mechanization. It also makes the movement of labour, machines and other farm inputs difficult and this may lead to land wastage as farmers tend to pay more attention to plots that are nearer to them (Niroula and Thapa 2007). Furthermore, farmers who applied fertilizer were less technically efficient than their counterparts who did not. This could mean that farmers who utilized fertilizers did not apply the recommended dosage as it is advisable to apply fertilizer doses after carrying out soil test. Consequently, they have not yielded the benefit of fertilizer application.

\section{CONCLUSION AND RECOMMENDATIONS}

Based on the findings, the study concluded that farmers in the study area were exposed to agrochemical related illnesses which in turn influences their technical efficiency negatively. The study, therefore, recommends the inclusion/enforcement of safety and health information pertaining to agrochemical use on extension packages. Also, farm inputs should be made easily accessible to younger farmers since they are more technically efficient and policies on land reforms should be tailored towards reducing land fragmentation in the study area. 


\section{REFERENCES}

Abeynayake N.R., Welagedara W.A.C.M., De Silva S.N.T., Fernando L.N.P. and Rathnayake A. (2015). Economic burden due to morbidity among farmers and non-farmers with type 2 diabetes in Dambadeniya Area, Sri Lanka. Int. Journal of Novel Research in Healthcare and Nursing, 2 (1) 51-57

Abubakar I. (2004). Resource Use Efficiency in Yam Production in Northern part of Taraba State, Nigeria. Unpublished M.Sc Dissertation, Department of Agricultural Economics and Extension, University of Maiduguri, Nigeria

Ajayi O.F. and Adeyemi A.A. (2016). Factors influencing the adoption of moringa plant cultivation among farming households in Southwestern Nigeria: A Tobit Approach. International Journal of Innovative Food, Nutrition \&Sustainable Agriculture, 4 (4), 15-24

Akinbode S.O., Dipeolu A.O. and Ayinde I.A. (2011). An examination of technical, allocative and economic efficiencies in Ofada rice farming in Ogun State , Nigeria. World Journal of Agricultural Sciences, 6 (28), 6027-6035

Alarima C.I. and Obikwelu F.E. (2018). Assessment of utilization of primary health care services among settled fulani agropastoralists in Ogun State, Nigeria. Agro-Science, 17 (1), 27-34

Asogwa E.U. and Dongo L.N (2009). Problems associated with pesticide usage and application in Nigerian cocoa production: a review. African Journal of Agricultural Research, 4 (8), 675-683

Bhatt M.S. and Bhat S.A. (2014). Technical efficiency and farm size productivity - micro level evidence from Jammu \& Kashmir. International Journal of Food \& Agricultural Economics, 2 (4), 27-49

Binuyo G., Abdulrahman S., Yusuf O. and Timothy A.J. (2016). Technical efficiency of rain-fed lowland rice production in Niger State, Nigeria. Asian J. Agric. Extension, Economics \& Sociology, 9 (4), 1-12 https://doi.org/10.9734/AJAEES/2016/22504

Dabady K. and Tulk P. (2015). Agrochemicals and Their Impact On Human Health: An Analysis of Pesticide Use and Incidences of Diseases in the Region of Rincón de Santa María. ENVR 451: Research in Panama, Final Report

Damalas C.A. and Eleftherohorinos I.G. (2011). Pesticide exposure, safety issues, and risk assessment indicators. Int. Jour. of Environmental Research and Public Health, 8, 1402-1419

Kakwagh V.V., Aderonmu J.A., and Ikwuba A. (2011). Land fragmentation and agricultural development in Tivland of Benue State, Nigeria. Current Research Journal of Social Sciences, 3 (2), 54-58

Kassali R., Ayanwale A.B. and Williams S.B. (2009). Farm location and determinants of agricultural productivity in the Oke-Ogun area of Oyo State Nigeria. J. of Sustainable Dev. in Africa, 11(2), 1-19

Krishna K., Ashok M. and Samarendu M. (2014). Determinants of rice productivity and technical efficiency in the Philippines: Selected Paper Prepared for Presentation at the Southern Agricultural Economics Association Annual Meeting, Dallas, Texas

Munungo S. and Chitungo K.S. (2013). The impact of farmers' health and nutritional status on agricultural technical efficiency: evidence from Masvingo rural communities. Journal of Agriculture and Sustainability, 3 (1), 1-15
NBS (2016). Nigeria Data Portal. www.nigeria.opendataforafrica.org

National Population Commission [Nigeria] (2014). 2014 Preliminary Revised Population Projections. Abuja, Nigeria: National Population Commission.

Niroula G.S. and Thapa, G.B. (2007). Impacts of land fragmentation on input use, crop yield and production efficiency in the mountains of Nepal. Land Degradation \& Development 18, 237-248

Niger State GIS (2007). Background Information. Retrieved on April 5 $5^{\text {th }} 2016$ from www.nigergis.com

Nzeka U., Taylor J. and Trego R. (2016). Nigeria Grain and Feed Annual. A report submitted to the USDA Foreign Agricultral Service. 4/21/2016

Obalum S.E., Nwite J.C., Watanabe Y., Igwe C.A. and Wakatsuki T. (2012). Comparative topsoil characterization of sawah rice fields in selected inland valleys around Bida, north-central Nigeria: physicochemical properties and fertility status. Tropical Agriculture \& Development, 56 (2), 39-48

Obalum S.E., Watanabe Y., Igwe C.A., Obi M.E. and Wakatsuki T. (2014). Puddling intensity for lateseason sawah systems based on soil hydrophysical conditions and rice performance. International Agrophysics, 28 (3), 331-340

Onyenekwe S.C. and Okorji E.C. (2015). Effects of offfarm work on the technical efficiency of rice farmers in Enugu State Nigeria. Journal of Agricultural Economics \& Development, 4 (4), 44-50

Polson R.A. and Spencer D.S.C. (1991). The technology adoption process in subsistence agriculture: the case of cassava in southwestern Nigeria. Agricultural System, 36, 65-78

Popp J., Peto K. and Nagy J. (2013). Pesticide productivity and food security. a review. Agronomy for Sustainable Development, 33, 243-225

Rahman K.M.M., Mia M.I. and Alam M.A. (2012). Farm-size-specific technical efficiency : a stochastic frontier analysis for rice growers in Bangladesh. Bangladesh Journal of Agricultural Economics, 35 (2), 131-142

Rosset P.M. (1999). The multiple Functions and benefits of small farm agriculture. Policy Brief No.4 Food First, The Institute for Food and Development Policy, 5 (10), 0-22. https://doi.org/10.1057/palgrave. development.1110149

SDSN (2013). Solutions for Sustainable Agriculture and Food Systems. Technical Report for the Post-2015 Development Agenda. Retrieved from www.unsdsn.org on 12/04/17

Tchale H. (2009). The efficiency of smallholder agriculture in Malawi. African Journal of Agricultural \& Resource Economics, (3) 2, 101-121

Truong N.C., Tran Q.T., Lisa L.P. and Mahabub M.H. (1999). Male and Female Rice Farmers' Perception of Insecticide and Health Problems: A Case Study of Vietnam International Rice Research Institute, Los Banos, Laguna, Philippines

WARA (2016). The Dangers of Self Medication. Retrieved from http://www.ghana.westafricanrescue.com/CMSPages/GetFile.aspx?guid=ff105b3f $-7 b 3 d-48 b 0-a d 4 c-b f 625 a 93868 b$

Ye M., Beach J. and Martin J. (2016). Occupational pesticide exposures and respiratory health. International Journal of Environmental Research and Public Health, 10 (12), 6442-6477 